\title{
PENGARUH LEVERAGE, PROFITABILITAS, DAN ECONOMIC VALUE ADDED (EVA) TERHADAP RETURN SAHAM PADA INDUSTRI MAKANAN DAN MINUMAN YANG TERDAFTAR DI BURSA EFEK INDONESIA (BEI) TAHUN 2012-2016
}

\author{
Hendro Sasongko dan Fara Shaliza \\ Fakultas Ekonomi Universitas Pakuan \\ Email: hendrosgk@gmail.com
}

ARTICLE INFO

Article History:

Received 1 August 2018

Revised 15 August 2018

Accepted 31 August 2018

\section{JEL Classification}

M41

Kata kunci:

Leverage,

Profitabilitas,

EVA, dan

Return Saham

\begin{abstract}
ABSTRAK
Penelitian ini bertujuan untuk mengetahui pengaruh leverage, profitabilitas, dan EVA terhadap return saham pada perusahaan makanan dan minuman yang terdaftar di Bursa Efek Indonesia (BEI). Populasi penelitian ini merupakan lima belas emiten perusahaan makanan dan minuman di BEI pada periode 2012-2016. Dengan menggunakan teknik purposive sampling, maka diperoleh sembilan sampel. Metode analisis yang digunakan terdiri dari uji asumsi klasik dan uji hipotesis dengan menggunakan SPSS 23. Hasil penelitian menunjukkan bahwa leverage berpengaruh terhadap return saham, yang berarti jika kesempatan investasi yang diperoleh perusahaan dilihat melalui DER mengalami kenaikan, maka memiliki hubungan dengan rasio return saham bagi investor. Profitabilitas dan EVA tidak berpengaruh terhadap return saham, yang berarti bahwa tinggi rendahnya profitabilitas dan EVA, tidak akan mempengaruhi keputusan investor terkait investasinya. Namun, secara simultan, variabel leverage, profitabilitas, dan EVA berpengaruh terhadap return saham.
\end{abstract}

\section{PENDAHULUAN}

Bagi seorang investor, investasi dalam sekuritas yang dipilih tentu diharapkan memberikan tingkat pengembalian (return) yang sesuai dengan risiko yang harus ditanggung oleh para investor (Novia, 2016). Tingkat return menjadi faktor utama dalam memilih investasi karena return merupakan hasil yang diperoleh dari suatu investasi (Damayanti, 2015).

Menurut Damayanti (2015) salah satu jenis sekuritas yang paling populer di pasar modal adalah sekuritas saham. Saham adalah surat berharga sebagai bukti penyertaan atau pemilikan individu atau institusi dalam perusahaan. Sedangkan menurut Husnan
(2012), saham adalah tanda bukti pengambilan bagian atau peserta dalam perusahaan terbuka (PT). Saham yang dinilai baik adalah saham yang mampu memberikan return realisasi yang tidak terlalu jauh dari return ekspektasi.

Investor yang memilih untuk berinvestasi di pasar modal dalam bentuk sekuritas saham berarti berinvestasi dalam prospek perusahaan tersebut. Perusahaan yang tergabung dalam pasar modal harus mampu meningkatkan nilai perusahaannya karena nilai perusahaan yang tinggi tentu memberikan gambaran yang baik dan peluang return yang besar. Apabila perusahaan menganggap semua investor adalah investor yang rasional maka dengan return ekspektasi 
yang tinggi tentu saja akan semakin banyak investor yang tertarik untuk membeli sekuritas yang dikeluarkan oleh perusahaan emiten sehingga tujuan pendanaan yang diinginkan perusahaan melalui pasar modal juga terpenuhi (Damayanti, 2015).

Tingkat pengembalian saham untuk satu periode tertentu adalah sama dengan jumlah selisih harga saham periode tertentu dengan periode sebelumnya, dibagi dengan harga saham periode sebelumnya (Jodi, 2011). Dengan demikian untuk mengetahui besarnya tingkat pengembalian yang diterima pemegang saham dalam sejumlah periode tertentu didasarkan pada tingkat pengembalian yang diharapkan. Menurut Novia $(2016,2)$ menyatakan bahwa keinginan investor untuk memperoleh return juga terjadi pada investasi dalam aset finansial. Suatu investasi aset finansial menunjukkan kesediaan investor menyediakan sejumlah dana pada saat ini untuk memperoleh aliran dana pada masa yang akan datang sebagai kompensasi atas faktor waktu selama dana ditanamkan dan risiko yang tertanggung. Dengan demikian, para investor sedang mempertaruhkan suatu nilai sekarang untuk sebuah nilai yang diharapkan pada masa yang akan datang.

Seiring dengan perkembangan pasar modal, kebutuhan akan informasi yang relevan dalam pengambilan keputusan oleh investor juga semakin meningkat. Kegiatan pasar modal tidak terlepas dari tersedianya berbagai macam informasi tentang emiten. Informasi bagi pelaku di lantai bursa tersebut akan mempengaruhi berbagai macam keputusan yang akan diambil yang berakibat pada perubahan atau fluktuasi baik harga maupun kualitas saham yang diperdagangkan. Dalam menentukan apakah investor akan melakukan transaksi di pasar modal, biasanya ia akan mendasarkan keputusan pada berbagai informasi yang dimilikinya (Novia, 2016). Informasi yang diperoleh dari kondisi intern perusahaan yang lazim digunakan adalah informasi laporan keuangan. Informasi ini digunakan sebagai dasar bagi investor untuk memprediksi return, risiko, atau ketidakpastian jumlah, waktu, dan faktor lain yang berhubungan dengan aktivitas di pasar modal (Fahmi, 2014, 279).

Penilaian kinerja keuangan perusahaan dapat dilakukan dengan menggunakan suatu alat ukur, yaitu analisis rasio keuangan. Analisis rasio keuangan didasarkan pada data laporan keuangan dan kondisi perusahaan di masa lalu sehingga dapat menilai kinerja yang dimiliki perusahaan. Kinerja keuangan perusahaan dapat dilihat dari kemampuan perusahaan menghasilkan laba, kemampuan perusahaan memenuhi kewajibannya (likuiditas), serta pengembalian perusahaan terhadap pemegang saham (investor). Banyak ahli mengemukakan hal yang sama, salah satunya Fahmi $(2012,44)$ mengemukakan "untuk melihat kemajuankemajuan atau potensi perusahaan yang paling utama ditinjau yaitu likuiditas, solvabilitas/leverage, rentabilitas atau profitabilitas, serta stabilitas usaha". Berdasarkan hal tersebut dan penelitian terdahulu peneliti menggunakan rasio penilai kinerja keuangan yang sering digunakan dan dianggap berpengaruh terhadap return saham yaitu rasio leverage (debt to equity ratio), profitabilitas (return on equity) dan economic value added (EVA).

Debt to equity ratio (DER) merupakan rasio leverage yang menggambarkan kemampuan modal suatu perusahaan dalam menjamin hutang yang dimiliki. Walter et al. (2011) mengatakan rasio "DER yang kecil menunjukkan bahwa perusahaan masih mampu memenuhi kewajibannya kepada kreditur". Hak kreditur terhadap aktiva perusahaan lebih besar dibandingkan dengan hak pemegang saham. Oleh karena itu, investor lebih menyukai DER yang lebih rendah, karena semakin rendah angka rasionya maka semakin kecil tingkat kerugian yang akan dialami oleh investor jika terjadi likuidasi atau kebangkrutan.

Perusahaan yang memiliki kinerja yang baik bisa dilihat dari profitabilitasnya. Artinya, perusahaan mampu memberikan keuntungan 
dan dapat memaksimalkan kesejahteraan kepada para pemegang sahamnya. Salah satu alat ukur profitabilitas adalah menggunakan Return on Equity (ROE) yang mengukur laba dibandingkan modal yang dimiliki perusahaan. Semakin tinggi angka ROE yang dihasilkan oleh suatu perusahaan maka semakin tinggi pula profitabilitasnya (Sari, 2016).

Bennet Stewart dan Joel M. Stern analis keuangan dari perusahaan Stern Stewart \& CO memperkenalkan salah satu cara menilai kinerja perusahaan yaitu Economic Value Added (EVA). EVA adalah alat ukur kinerja keuangan untuk memperhitungkan keuntungan ekonomis perusahaan sebenarnya. EVA dapat diperhitungkan dengan laba bersih setelah pajak dikurang biaya modal yang diinvestasikan. EVA yang bernilai positif berarti perusahaan dianggap telah mampu menciptakan nilai bagi pemegang saham karena mampu menghasilkan laba operasi di atas biaya modal.

EVA berbeda dengan perhitungan kinerja yang berbasis rasio. EVA mengikutsertakan perhitungan biaya modal yang dimiliki perusahaan. Biaya modal merupakan biaya yang dikeluarkan dalam rangka memperoleh modal untuk menjalankan kegiatan operasionalnya sehingga tercapai tujuan perusahaan. Laba operasi di atas biaya modal menunjukkan perusahaan telah mampu menciptakan nilai bagi pemegang saham. Ketika semakin besar value added yang diciptakan oleh perusahaan maka akan semakin tinggi pula potensi keuntungan bagi investor.

SWA melakukan pemeringkatan terhadap 100 perusahaan publik pada tahun 2003 hingga 2006. Hasilnya ada 24 perusahaan mencetak EVA positif pada tahun 2003, 31 perusahaan pada tahun 2004, 56 perusahaan pada tahun 2005, dan 33 perusahaan pada tahun 2006. Hasil pemeringkatan ini menunjukkan bahwa masih sedikit perusahaan publik dalam negeri yang mampu menciptakan nilai bagi pemegang saham. Nilai bagi pemegang saham merupakan keuntungan yang ia dapatkan atas investasi yang dilakukannya.

Penelitian Ansori (2015) menguji pengaruh EVA dan market value added terhadap return saham pada perusahaan manufaktur yang terdaftar di Bursa Efek Indonesia menunjukan hasil bahwa EVA dan market value added berpengaruh positif dan signifikan terhadap return saham. Safitri, dkk. (2015) menganalisis pengaruh profitabilitas, likuiditas, dan leverage terhadap return saham pada perusahaan manufaktur yang terdaftar di BEI tahun 2009-2013 menunjukkan hasil bahwa, (1) profitabilitas berpengaruh positif dan signifikan terhadap return saham, (2) likuiditas berpengaruh positif dan signifikan terhadap return saham, (3) leverage berpengaruh positif dan signifikan terhadap return saham, (4) profitabilitas, likuiditas, dan leverage secara bersama-sama berpengaruh positif dan signifikan terhadap return saham.

Hasil penelitian Gejali dan Satrio (2013), Sari dan Sugiyoni (2016) dan Qodari dan Hening (2017) menyatakan bahwa ROE berpengaruh signifikan terhadap return saham. Hasilnya yang berbeda didapatkan oleh Aisah dan Mandala (2016) yang menyatakan tidak adanya pengaruh ROE terhadap return saham.

Penelitian ini dilakukan berdasarkan temuan-temuan empiris mengenai leverage, profitabilitas, dan EVA yang telah diuji sebelumnya. Karena ketidakkonsistenan akan kesimpulan akhir penelitian yang ada mendorong peneliti untuk melakukan penelitian lanjutan yang dapat memberikan hasil yang lebih memadai dan data yang relevan pada kondisi saat ini. Lalu untuk perusahaan peneliti menggunakan perusahaan manufaktur kategori makanan dan minuman di Bursa Efek Indonesia.

Berikut disajikan perkembangan return saham yang termasuk dalam perusahaan makanan dan minuman yang terdaftar di BEI tahun 2012-2016. 


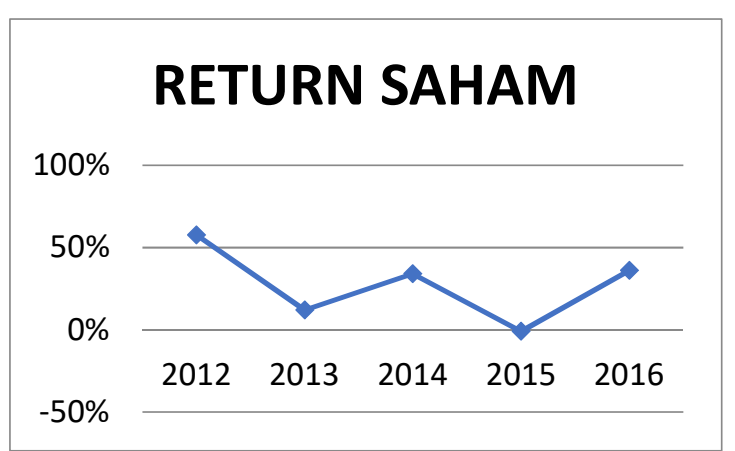

Sumber: www.sahamok.com data diolah, 2017

Gambar 1. Perkembangan Return Saham Perusahaan Makanan dan Minuman tahun 2012-2016

Dari grafik perkembangan return saham pada Gambar 1 tersebut, dapat dilihat bahwa di perusahaan yang termasuk dalam perusahaan makanan dan minuman mengalami fluktuatif setiap tahunnya. Pada tahun 2012, perusahaan makanan dan minuman memiliki tingkat return saham sebesar 57,6\%. Pada tahun 2013 mengalami penurunan sebesar 11,66\%. Pada tahun 2014 mengalami peningkatan tingkat return saham yaitu sebesar 34,40\%. Pada tahun 2015, perusahaan makanan dan minuman mengalami penurunan sebesar $-0,93 \%$. Pada tahun 2016 tingkat return saham perusahaan makanan dan minuman sebesar $36,44 \%$. Hal ini dikarenakan adanya perbedaan tinggi dan rendahnya harga saham pada perusahaan tersebut. Apabila harga saham lebih tinggi dari harga sebelumnya maka return saham akan naik, namun apabila harga saham lebih rendah dari harga saham sebelumnya maka return saham akan turun. Fluktuatif return saham tersebut dipengaruhi oleh beberapa faktor sehingga perlu diteliti lebih lanjut faktor-faktor apa saja yang menjadi penyebabnya.

Ada pun tujuan penelitian ini adalah untuk mengetahui pengaruh leverage, EVA, dan profitabilitas terhadap return saham pada perusahaan makanan dan minuman terdaftar di Bursa Efek Indonesia (BEI) tahun 2012-2016.

\section{TELAAH TEORI \\ Return Saham}

Return saham adalah keuntungan yang diperoleh oleh perusahaan, individu, dan institusi dari hasil kebijakan investasi saham yang dilakukannya. Return saham bisa berupa penerimaan dividen tunai ataupun adanya perubahan harga saham. Tingkat keuntungan investasi dalam saham di pasar modal sangat ditentukan oleh harga saham yang bersangkutan. Oleh karena itu, untuk memprediksi return yang akan diterima pemodal harus mengetahui faktor-faktor yang mempengaruhi harga saham. Faktor yang mempengaruhi return suatu investasi meliputi faktor internal dan faktor eksternal perusahaan. Faktor internal perusahaan meliputi kualitas dan reputasi manajemen, struktur hutang, tingkat laba yang dicapai dan lain-lain. Sedangkan faktor eksternal meliputi pengaruh kebijakan moneter dan fiskal, perkembangan sektor industri, faktor ekonomi dan sebagainya.

Apabila harga saham sekarang lebih tinggi dari harga sebelumnya maka hal ini berarti terjadi keuntungan modal (capital gain) dan return yang diterima bernilai positif, begitu pula sebaliknya apabila harga saham sekarang lebih rendah dari harga sebelumnya maka hal ini berarti terjadi kerugian (capital loss) dan return yang diterima bernilai negatif. Return saham diturunkan dari perubahan harga saham, return merupakan hasil yang diperoleh dari investasi. Semakin tinggi harga saham, maka semakin menunjukkan bahwa saham tersebut semakin diminati investor karena dengan semakin tinggi harga saham akan memberikan keuntungan.

Return saham merupakan hasil yang diterima atau diharapkan investor dari investasi saham yang dilakukannya. Return yang digunakan dalam penelitian ini merupakan return yang telah terjadi yang dihitung berdasarkan data historis dan digunakan sebagai salah satu pengukur kinerja perusahaan. Return realisasi ini juga berguna sebagai dasar penentuan return ekspektasi 
(expected return) yang merupakan return yang diharapkan oleh investor di masa mendatang.

Return realisasi yang digunakan dalam penelitian ini adalah capital gain. Menurut Fahmi $(2014,328)$, besarnya capital gain dapat dihitung dengan rumus:

$C G=\frac{P_{i t}-P_{i t-1}}{P_{i t-1}}$

Keterangan:

CG = Capital gain

$\mathrm{P}_{\mathrm{it}} \quad=$ Harga saham akhir periode

$\mathrm{P}_{\mathrm{it}-1}=$ Harga saham akhir periode sebelumnya

\section{Leverage}

Leverage merupakan rasio yang digunakan untuk mengukur sejauh mana aset perusahaan dibiayai dengan utang. Dengan kata lain, leverage merupakan rasio yang digunakan untuk mengukur seberapa besar beban utang yang ditanggung perusahaan dalam rangka pemenuhan aset. Dalam arti luas, leverage digunakan untuk mengukur kemampuan perusahaan dalam memenuhi seluruh kewajibannya, baik kewajiban jangka pendek maupun jangka panjang.

Perusahaan dengan leverage yang tinggi dapat berdampak pada timbulnya risiko keuangan yang besar, tetapi juga memiliki peluang yang besar pula untuk menghasilkan laba yang tinggi. Risiko keuangan yang besar ini timbul karena perusahaan harus menanggung pembayaran bunga dalam jumlah yang besar. Namun, apabila hasil pinjaman tersebut dipergunakan secara efisien dan efektif dengan membeli aset produktif tertentu (seperti mesin dan peralatan) atau untuk membiayai ekspansi bisnis perusahaan akan memberikan peluang yang besar bagi perusahaan untuk meningkatkan hasil usahanya.

Sebaliknya, perusahaan dengan leverage yang rendah memiliki risiko keuangan yang kecil, tetapi juga mungkin memiliki peluang yang kecil pula untuk menghasilkan laba yang besar. Seorang manajer keuangan yang andal dituntut untuk memiliki kepiawaian dalam mengelola utang perusahaan, khususnya dalam mencermati hubungan antara risiko keuangan dengan tingkat pengembalian yang dihasilkan dari dana yang dipinjam perusahaan.

Rasio keuangan yang digunakan untuk mengukur leverage perusahaan yaitu dengan menggunakan Debt to Total Equity Ratio (DER). DER diperoleh dari membagi total hutang perusahaan dengan total ekuitasnya. Rasio ini menggambarkan mengenai struktur modal yang dimiliki oleh perusahaan yang berasal dari utang jangka panjang dan modal yang berasal dari ekuitas. Jika hasil perhitungan semakin besar, menunjukkan bahwa struktur modal yang berasal dari utang semakin besar untuk digunakan mendanai ekuitas yang ada.

Leverage dengan proksi DER dapat dihitung dengan cara (Ulupui, 2007, 9):

$D E R=\frac{\text { Total utang }}{\text { Total ekuitas }}$

\section{Profitabilitas}

Profitabilitas merupakan rasio yang menggambarkan kemampuan perusahaan mendapatkan laba melalui semua kemampuan dan sumber yang ada, seperti kegiatan penjualan, kas, ekuitas, jumlah karyawan, jumlah cabang, dan sebagainya (Harahap, 2009). Salah satu proksi profitabilitas adalah Return On Equity (ROE). ROE digunakan untuk mengukur seberapa banyak keuntungan yang menjadi hak pemilik modal sendiri (Qodari dan Oetomo, 2017). ROE tinggi menunjukkan tingkat profitabilitas yang tinggi. Menurut Gejali dan Satrio (2013), apabila perusahaan dapat menghasilkan ROE tinggi, maka investor menganggap bahwa perusahaan telah menggunakan modalnya dengan seefisien dan seefektif mungkin. Artinya, hal itu akan memberikan jaminan pada investor untuk memperoleh laba yang diharapkan.

Profitabilitas dengan proksi ROE dihitung dengan cara (Gejali dan Satrio 2013): 
$R O E=\frac{E B I T}{\text { Total ekuitas }}$

\section{Economic Value Added (EVA)}

EVA menurut Hansen dan Mowen (2009, 585) adalah laba bersih (laba operasi setelah pajak) dikurangi total biaya modal tahunan. EVA merupakan ukuran nilai tambah ekonomis yang dihasilkan perusahaan sebagai akibat dari aktifitas atau strategi manajemen. Jika EVA positif, maka perusahaan telah menciptakan kekayaan. Tetapi jika EVA negatif, maka perusahaan telah merusak modalnya. EVA juga menghasilkan tingkat pengembalian seperti ROI karena menghubungkan penghasilan bersih (pengembalian) dengan modal yang dipakai. Intinya, EVA menekankan pada laba operasi setelah pajak dan biaya aktual dari modal. EVA sebagai alat penilaian kinerja berdasarkan value based pada dasarnya berfungsi sebagai indikator kinerja sebuah perusahaan dalam setiap kegiatan operasional ekonomisnya.

Indikator EVA menurut Kartini dan Hermawan (2008) yaitu:

1. Bila EVA $<0$ menunjukkan nilai perusahaan berkurang sebagai akibat tingkat pengembalian yang dihasilkan lebih rendah daripada tingkat pengembalian yang diharapkan penyedia dana atau dengan kata lain tidak ada nilai tambah pada perusahaan tersebut karena laba yang tersedia tidak memenuhi harapan - harapan para penyedia dana terutama pemegang saham.

2. Bila $E V A=0$ artinya bahwa perusahaan secara ekonomis berada dalam keadaan impas karena semua laba yang tersedia telah digunakan untuk membayar kewajiban kepada penyedia dana, baik kreditur maupun pemegang saham.

3. Bila EVA $>0$ memiliki arti bahwa tingkat pengembalian yang dihasilkan melebihi tingkat biaya modal/tingkat yang diminta investor atas investasi yang dilakukannya. Keadaan seperti ini yang menunjukkan bahwa perusahaan telah berhasil menciptakan nilai bagi pemilik modal karena telah memaksimalkan nilai perusahaan.

EVA ditentukan oleh dua hal yaitu keuntungan bersih setelah pajak dan tingkat biaya modal. Laba operasi setelah pajak menggambarkan hasil penciptaan nilai di perusahaan, sedangkan biaya modal merupakan pengorbanan yang harus dikeluarkan untuk mendapatkan nilai tersebut.

EVA dapat dihitung dengan cara berikut (Kartini dan Hermawan, 2008:362):

$$
E V A=N O P A T-(W A C C \times \text { Invested Capital })
$$

Keterangan:

NOPAT = Net Operating Profit After Tax

$$
=\text { EBIT }- \text { Tax Expense }
$$

WACC = Weighted Average Cost of Capital $=$ (Biaya Ekuitas $x$ Presentasi Ekuitas)

$\mathrm{x}$ (Biaya Utang $\mathrm{x}$ Presentase Utang)

Invested Capital $=$ Modal yang diinvestasikan

\section{Kerangka Pemikiran dan Pengembangan Hipotesis}

Perusahaan yang menggunakan utang dalam membiayai perusahaannya berarti mempunyai kewajiban tetap berupa bunga yang harus dibayar tunai dalam kaitannya dengan arus kas perusahaan. Leverage adalah penggunaan sumber dana yang memiliki beban tetap dengan harapan bahwa akan memberikan tambahan keuntungan yang lebih besar daripada beban tetapnya sehingga akan meningkatkan keuntungan yang tersedia bagi pemegang saham. Perusahaan yang memiliki rasio utang yang lebih besar seharusnya membagikan dividen lebih kecil karena laba yang diperoleh digunakan untuk melunasi kewajiban. Dengan demikian investor dapat mempelajari kewajiban perusahaan untuk memperkirakan pendapatan dari investasi berupa dividen, di masa yang akan datang. Oleh karena itu, tingkat utang yang memiliki hubungan tidak searah (negatif) dengan tingkat pengembalian investasi berupa dividen. Tingkat leverage perusahaan investee berhubungan negatif dengan tingkat 
pengembalian investasi berupa dividen bagi investor karena tingkat leverage menunjukkan bahwa investee melunasi kewajibannya dari laba yang ada sehingga dividen yang dibagikan ke investor lebih kecil. Dari hal tersebut maka dapat diduga bahwa leverage berpegaruh terhadap return saham.

Hal berikutnya yang akan dilihat oleh investor adalah profitabilitas. Semakin tinggi profitabilitas maka investor berharap return saham yang dihasilkan semakin besar. Dari hal tersebut maka dapat diduga bahwa profitabilitas berpengaruh terhadap return saham.

Informasi lain yang dapat digunakan oleh investor adalah dilihat dari economic value added. EVA merupakan pengukuran kinerja yang memperhitungkan tingkat biaya modal, yaitu dengan perhitungan laba bersih setelah pajak dikurangi dengan biaya modal. EVA positif menunjukkan perusahaan berhasil memenuhi biaya modal dengan laba bersih setelah pajak, sehingga para pemegang saham akan menerima return dari perusahaan tersebut. Semakin tinggi EVA, maka semakin tinggi return yang diperoleh pemegang saham. Maka, diduga EVA terhadap return saham.

Secara sistematis kerangka pemikiran disajikan sebagai berikut:

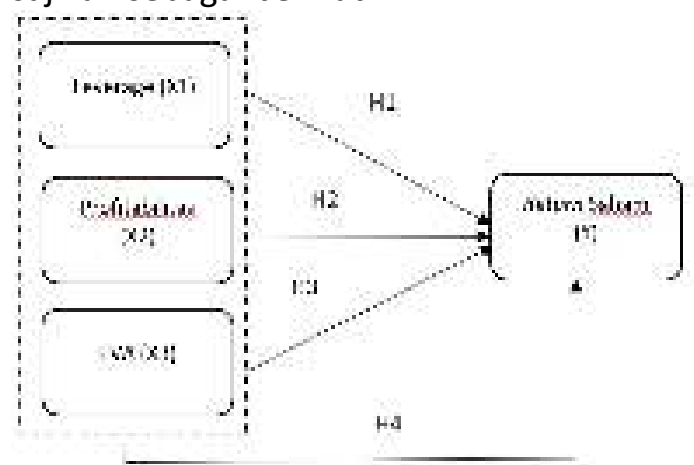

Gambar 2. Kerangka Pemikiran

Berdasarkan kerangka pemikiran teoretis, maka perumusan hipotesis yang dikembangkan adalah sebagai berikut:

$\mathrm{H} 1$ : Leverage berpengaruh terhadap return saham pada perusahaan makanan dan minuman yang terdaftar di Bursa Efek Indonesia (BEI) tahun 2012-2016.

$\mathrm{H} 2$ : Profitabilitas berpengaruh terhadap return saham pada perusahaan makanan dan minuman yang terdaftar di Bursa Efek Indonesia (BEI) tahun 2012-2016.

H3: EVA berpengaruh terhadap return saham pada perusahaan makanan dan minuman yang terdaftar di Bursa Efek Indonesia (BEI) tahun 2012-2016.

H4: Leverage, Profitabilitas, dan EVA berpengaruh terhadap return saham pada perusahaan makanan dan minuman yang terdaftar di Bursa Efek Indonesia (BEI) tahun 2012-2016.

\section{METODE PENELITIAN}

\section{Jenis Penelitian}

Jenis penelitian yang digunakan adalah penelitian verifikatif mengenai pengaruh leverage, profitabilitas, dan EVA terhadap return saham pada perusahaan makanan dan minuman yang terdaftar di Bursa Efek Indonesia. Penelitian ini akan dibuktikan dengan menggunakan metode analisis statistik. Sampel penelitian diperoleh dengan memanfaatkan laporan keuangan perusahaan makanan dan minuman yang terdaftar di Bursa Efek Indonesia tahun 2012-2016.

\section{Objek, Unit Analisis, dan Lokasi Penelitian}

Objek pada penelitian ini adalah variabel-variabel yang meliputi leverage, profitabilitas, dan EVA serta pengaruhnya terhadap return saham. Untuk memperoleh data dan informasi yang diperlukan maka penulis melakukan penelitian atas variabelvariabel tersebut pada perusahaan makanan dan minuman yang terdaftar di Bursa Efek Indonesia.

Unit analisis yang digunakan dalam penelitian ini adalah berupa organization, yaitu sumber data yang unit analisis nya merupakan respon dari divisi organisasi/perusahaan. Dalam hal ini unit analisis adalah divisi organisasi yaitu perusahaam makanan dan 
Hendro Sasongko: Pengaruh Leverage... minuman yang terdaftar di Bursa Efek
Indonesia.

Lokasi dalam penelitian ini adalah perusahaan makanan dan minuman. Penelitian ini merupakan penelitian sekunder maka dari itu lokasi penelitian nya diperoleh melalui situs Bursa Efek Indonesia (www.idx.co.id).

\section{Populasi dan Sampel}

Populasi dalam penelitian ini adalah lima belas perusahaan makanan dan minuman yang terdaftar pada Bursa Efek Indonesia (BEI) pada periode tahun 2012-2016. Dari jumlah populasi tersebut, sembilan perusahaan dijadikan sampel penelitian dengan menggunakan purposive sampling, yaitu perusahaan makanan dan minuman yang terdaftar di Bursa Efek Indonesia secara konsisten selama periode pengamatan tahun 2012-2016. Sebanyak dua perusahaan tidak menerbitkan laporan keuangan yang telah diaudit untuk tahun yang berakhir 2012-2016. Kemudian, sebanyak dua perusahaan tidak dijadikan sampel karena mengalami kerugian selama pengamatan. Angka laba negatif menjadi tidak bermakna. Terakhir, terdapat dua data perusahaan yang outlier. Ada pun sembilan perusahaan itu adalah PT Tiga Pilar Sejahtera Food Tbk, PT Wilmar Cahaya Indonesia Tbk, PT Indofood CBP Sukses Makmur Tbk, PT Indofood Sukses Makmur Tbk, PT Mayora Indah Tbk, PT Nippon Indosari Corpindo Tbk, PT Sekar Laut Tbk, PT Siantar Top Tbk, dan PT Delta Djakarta Tbk.

\section{Operasionalisasi Variabel}

Untuk memudahkan proses analisis, maka terlebih dahulu penulis mengklasifikasikan variabel-variabel penelitian, yaitu sebagai berikut:

Tabel 1. Operasional Variabel

\begin{tabular}{l|l|l|l}
\hline Variabel & Indikator & Ukuran & Skala \\
\hline Leverage & $\begin{array}{l}\text { Debt to } \\
\text { Equity } \\
\text { Ratio }\end{array}$ & $\frac{\text { Total utang }}{\text { Total ekuitas }}$ & Rasio \\
\hline Profitabilitas & $\begin{array}{l}\text { Return } \\
\text { on Equity }\end{array}$ & $\frac{\text { EBIT }}{\text { Total ekuitas }}$ & Rasio \\
\hline
\end{tabular}

\begin{tabular}{c|l|l|l}
\hline Variabel & Indikator & Ukuran & Skala \\
\hline $\begin{array}{l}\text { Economic } \\
\text { Value Added }\end{array}$ & EVA & $\begin{array}{l}\text { NOPAT - } \\
\text { (WACC } \mathrm{x} \\
\text { Invested } \\
\text { Capital) }\end{array}$ & Rasio \\
\hline $\begin{array}{l}\text { Return } \\
\text { Saham }\end{array}$ & $\begin{array}{l}\text { Capital } \\
\text { Gain }\end{array}$ & $\frac{P_{i t}-P_{i t-1}}{P_{i t-1}}$ & Rasio \\
\hline
\end{tabular}

Sumber: Jurnal-jurnal terdahulu (2017)

\section{Metode Analisis}

Analisis regresi linier berganda digunakan untuk mengetahui bagaimana hubungan antara dua variabel (atau lebih) atau sub variabel (positif atau negatif) dan bagaimana signifikansi atau seberapa erat hubungan antara dua variabel (independen atau dependen). Formulasi persamaan analisis regresi linier berganda dalam penelitian ini adalah sebagai berikut:

$$
\begin{gathered}
\text { Return }=a+b_{1} D E R+b_{2} R O E+b_{3} E V A \\
+e
\end{gathered}
$$

Langkah-langkah analisis data dan pengujian hipotesis yang akan dilakukan adalah dengan uji asumsi klasik dan uji hipotesis.

\section{HASIL PENELITIAN DAN PEMBAHASAN Uji Normalitas}

Uji normalitas bertujuan untuk menguji apakah dalam model regresi, variabel pengganggu atau residual memiliki distribusi normal. Seperti diketahui bahwa uji t atau uji $\mathrm{F}$ mengasumsikan bahwa nilai residual mengikuti distribusi normal. Jika asumsi ini dilanggar maka uji statistik menjadi tidak valid untuk jumlah sampel kecil.

Tabel 2. Uji Normalitas

One-Sample Kolmogorov-Smirnov Test

\begin{tabular}{l|r}
\hline & $\begin{array}{c}\text { Unstandardized } \\
\text { Residual }\end{array}$ \\
\hline Asymp. Sig. (2-tailed) &, $062^{\mathrm{c}}$ \\
\hline
\end{tabular}
a. Test distribution is Normal.
b. Calculated from data.
c. Lilliefors Significance Correction. 
Pada tabel One-Sample KolmogorovSmirnov Test menunjukkan signifikansi $0,062>0,05$. Hal ini menunjukkan bahwa data penelitian terdistribusi secara normal.

\section{Uji Multikolinearitas}

Uji multikolonieritas bertujuan untuk menguji apakah model regresi ditemukan adanya korelasi antar variabel bebas (Ghozali, 2013, 105). Model regresi yang baik seharusnya tidak terjadi korelasi diantara variabel-variabel ini tidak orthogonal. Variabel orthogonal adalah variabel independen yang nilai korelasi antar sesama variabel independen sama dengan nol. Untuk mendeteksi ada atau tidaknya multikolonieritas di dalam model regresi dapat dilihat dari nilai tolerance dan VIF (Variance Inflation Factor).

Tabel 3. Uji Multikolinearitas

\begin{tabular}{l|l|r|r}
\hline \multirow{2}{*}{ Model } & \multicolumn{2}{c}{ Collinearity Statistics } \\
\cline { 3 - 4 } \multicolumn{2}{l}{1} & Tolerance & \multicolumn{1}{c}{ VIF } \\
\cline { 3 - 4 } & (Constant) & & \\
\cline { 2 - 4 } & EVA &, 986 & 1,015 \\
\cline { 2 - 4 } & DER &, 997 & 1,003 \\
\cline { 2 - 4 } & ROE &, 986 & 1,014 \\
\hline \multicolumn{2}{l}{ Kenudian }
\end{tabular}

Kemudian, apabila melihat tabel Collinearity Statistics, tidak terdapat masalah multikolineatitas karena tolerance $>0,1$ dan VIF $<10$.

\section{Uji Autokorelasi}

Uji autokorelasi bertujuan menguji apakah dalam model regresi ada korelasi antara kesalahan pengganggu pada periode $t$ dengan kesalahan pengganggu pada periode $t$ dengan kesalahan pengganggu pada periode $\mathrm{t}-1$ (sebelumnya). Jika terjadi korelasi maka dinamakan ada problem autokorelasi. Autokorelasi muncul karena observasi yang berurutan sepanjang waktu berkaitan satu sama lainnya. Masalah ini timbul karena residual (kesalahan pengganggu) tidak bebas dari satu observasi ke observasi lainnya (Ghozali, 2013, 110). Syarat tidak adanya autokorelasi yaitu jika dU $<\mathrm{dW}<4-\mathrm{dU}$.
Tabel 4. Uji Autokorelasi

Model Summary ${ }^{b}$

\begin{tabular}{l|r}
\hline Model & Durbin-Watson \\
\hline 1 & 1,832 \\
\hline
\end{tabular}

Dari hasil uji autokorelasi dengan menggunakan Durbin-Watson yang menunjukkan hasil sebesar 1,832. Kemudian, dibandingkan dengan tabel DW dengan $\mathrm{df}=4$ dan $\mathrm{n}=45$ maka dU sebesar 1,72 dan 4-dU sebesar 2,28. Hal tersebut menunjukkan tidak adanya masalah autokorelasi karena 1,72 < $1,832<2,28$.

\section{Uji Heteroskedastisitas}

Uji heterokedasitas bertujuan untuk menguji apakah dalam model regresi terjadi ketidaksamaan varians dan residual satu pengamatan ke pengamatan yang lain. Jika varians dan residual satu ke pengamatan yang lain tetap, maka disebut Homoskedasitas dan jika berbeda disebut Heteroskedasitas. Model regresi yang baik adalah Homoskedasitas atau tidak terjadi Heterokedasitas (Ghozali, 2013, 139).

Tabel 5. Uji Heteroskedastisitas

\begin{tabular}{l|l}
\hline \multicolumn{2}{c}{ Spearman's rho } \\
\hline Variabel & Sig. (2-tailed) \\
\hline EVA & 0,715 \\
\hline DER & 0,243 \\
\hline ROE & 0,717 \\
\hline
\end{tabular}

Uji asumsi klasik terakhir, yaitu uji heteroskedastisitas menunjukan bahwa variabel independen tidak terdapat masalah heteroskedastisitas karena signifikansi >0,05.

\section{Uji Hipotesis}

Tabel 6. Koefisien Determinasi Model Summary ${ }^{b}$

\begin{tabular}{l|l|r|r|r}
\hline $\begin{array}{l}\text { Mod } \\
\text { el }\end{array}$ & $\mathrm{R}$ & $\begin{array}{c}\mathrm{R} \\
\text { Square }\end{array}$ & $\begin{array}{c}\text { Adjusted R } \\
\text { Square }\end{array}$ & $\begin{array}{c}\text { Std. Error } \\
\text { of the } \\
\text { Estimate }\end{array}$ \\
\hline 1 &, $477^{\mathrm{a}}$ &, 227 &, 171 &, 71912 \\
\hline
\end{tabular}

a. Predictors: (Constant), ROE, DER, EVA

b. Dependent Variable: Return 
$R$ Square $\left(R^{2}\right)$ menunjukkan nilai koefisien determinasi yaitu persentase sumbangan pengaruh variabel independen terhadap variabel dependen jika dalam regresi menggunakan tidak lebih dari dua variabel independen. Nilai $R$ Square sebesar 0.227 yang berarti bahwa variabel independen (leverage, profitabilitas, dan EVA) mempengaruhi variabel dependen (return saham) sebesar $22,7 \%$ dan sisanya $77,3 \%$ dipengaruhi oleh variabel lain yang tidak dijelaskan dalam penelitian ini.

\section{Analisis Regresi Berganda}

Analisis Regresi Linier Berganda digunakan untuk menentukan seberapa besar pengaruh variabel independen terhadap variabel dependennya. Tujuan utama untuk mengukur besarnya pengaruh secara kuantitatif dari perubahan variabel dependen atas dasar nilai variabel independen.

Tabel 8. Analisis Regresi Berganda Coefficients $^{\mathrm{a}}$

\begin{tabular}{l|l|r|r}
\hline \multicolumn{2}{l|}{ Model } & \multicolumn{2}{c}{ Unstandardized Coefficients } \\
\cline { 3 - 4 } & \multicolumn{1}{c}{ B } & \multicolumn{1}{c}{ Std. Error } \\
\hline \multirow{4}{*}{1} & (Constant) &,- 940 &, 328 \\
\cline { 2 - 4 } & EVA & $2,963 \mathrm{E}-10$ &, 000 \\
\cline { 2 - 4 } & DER & 1,011 &, 292 \\
\cline { 2 - 4 } & ROE &, 003 &, 449 \\
\hline
\end{tabular}

a. Dependent Variable: Return

Hasil pada Tabel 8 dapat dilihat model persamaan regresi linier berganda sebagai berikut:

$Y=a+b 1 X 1+b 2 X 2+b 3 X 3+e$

$Y=-0,940+1,011$ DER + 0,003 ROE + 2,963E10 EVA + e

Keterangan :

$\mathrm{Y}=$ Return Saham, proksi Capital Gain (CG)

a = Nilai Konstanta

$\mathrm{X} 1$ = Leverage, indikator Debt to Equity Ratio (DER)

$\mathrm{X} 2$ = Profitabilitas, indikator Return on Equity

(ROE)

$\mathrm{X} 3=$ Economic Value Added (EVA) b1 = Koefisien regresi variabel leverage

b2 = Koefisien regresi variabel proftabilitas

b3 = Koefisien regresi variabel economic value added

$\mathrm{e}=$ Disturbance error

Dari persamaan model regresi linier berganda tersebut dijelaskan sebagai berikut:

1. Konstanta

Konstanta sebesar -0,940 artinya jika leverage dan economic value added nilainya adalah 0 , maka capital gain nilainya negatif sebesar $-0,940$.

2. Koefisien Regresi Variabel Leverage Nilai koefisien regresi variabel leverage (b1) bernilai positif 1,011 artinya apabila leverage naik sebesar satu satuan sedangkan variabel lainnya dianggap konstan, maka capital gain akan mengalami kenaikan sebesar 1,011 satuan.

3. Koefisien Regresi Variabel Profitabilitas Nilai koefisien regresi variabel profitabilitas (b2) bernilai positif 0,003 artinya apabila profitabilitas naik sebesar satu satuan sedangkan variabel lainnya dianggap konstan, maka capital gain akan mengalami kenaikan sebesar 0,003 satuan.

4. Koefisien Regresi Economic Value Added Nilai koefisien regresi variabel economic value added (b3) bernilai positif 2,963E-10 artinya apabila economic value added naik sebesar satu satuan sedangkan variabel lainnya dianggap konstan, maka capital gain akan mengalami penurunan sebesar 2,963E-10 satuan.

\section{Uji Signifikansi Parameter Individual (Uji t)}

Uji statistik $t$ menunjukkan seberapa jauh pengaruh satu variabel penjelas atau independen secara individual dalam menerangkan variasi variabel dependen (Ghozali, 2013, 98). Jika hasil perhitungan nilai signifikan kurang dari $\alpha 5 \%$ menyatakan bahwa suatu variabel independen secara individual mempengaruhi variabel dependen. 
Tabel 7. Uji t

Coefficients $^{\mathrm{a}}$

\begin{tabular}{l|l|r|r}
\hline \multicolumn{2}{l|}{ Model } & \multicolumn{1}{c}{ t } & \multicolumn{1}{c}{ Sig. } \\
\hline \multirow{3}{*}{1} & (Constant) & $-2,868$ &, 007 \\
\cline { 2 - 4 } & EVA &, 446 &, 658 \\
\cline { 2 - 4 } & DER & 3,457 &, 001 \\
\cline { 2 - 4 } & ROE &, 008 &, 994 \\
\hline
\end{tabular}

a. Dependent Variable: Return

Dari tabel 7 menunjukkan bahwa hanya variabel leverage dengan indikator DER berpengaruh terhadap return saham karena signifikansi $0,01<0,05$. Sedangkan variabel EVA dan profitabilitas tidak berpengaruh terhadap return saham karena signifikansi keduanya > 0,05 .

\section{Uji Koefisien Simultan (Uji F)}

Uji statistik $F$ menunjukkan apakah semua variabel independen atau bebas yang dimasukkan dalam model mempunyai pengaruh secara bersama - sama terhadap variabel dependen atau variabel terikat (Ghozali, 2013, 98). Menurut Ghozali (2013, 98), jika hasil perhitungan nilai signifikan kurang dari $\alpha$ 5\% menyatakan bahwa semua variabel independen secara serentak dan signifikan mempengaruhi variabel dependen.

\begin{tabular}{|c|c|c|c|}
\hline \multicolumn{4}{|c|}{$\begin{array}{c}\text { Tabel 8. Uji F } \\
\text { ANOVA }^{\mathrm{a}}\end{array}$} \\
\hline \multicolumn{2}{|c|}{ Model } & $\mathrm{F}$ & Sig. \\
\hline \multirow[t]{3}{*}{1} & Regression & 4,019 &, $013^{b}$ \\
\hline & Residual & & \\
\hline & Total & & \\
\hline
\end{tabular}

a. Dependent Variable: Return

b. Predictors: (Constant), ROE, DER, EVA

Dari tabel 8 menunjukkan bahwa secara bersama-sama leverage, profitabilitas, dan EVA berpengaruh terhadap return saham karena signifikansi 0,013<0,05.

\section{Pembahasan}

Pengaruh Leverage terhadap Return Saham Leverage dengan menggunakan indikator DER berpengaruh terhadap return saham yang berarti jika kesempatan investasi yang diperoleh perusahaan dilihat melalui DER mengalami kenaikan, maka akan ada hubungannya dengan return saham bagi investor. Hasil ini sejalan dengan penelitian yang dilakukan oleh Safitri (2015) yang menyatakan bahwa Debt to Equity Ratio (DER) secara parsial berpengaruh signifikan terhadap return saham. Hasil dari penelitian ini sesuai dengan teori menurut Ulupui $(2007,9)$ bahwa leverage dapat membantu investor dan perusahaan untuk berinvestasi atau beroperasi namun dengan risiko yang lebih besar yaitu risiko bagi pemberi pinjaman. Adanya pengaruh yang signifikan dari leverage terhadap return saham terjadi karena investor dalam melakukan investasi memandang penting penggunaan hutang maupun pengembalian harga bunga dan pokok hutang yang pada akhirnya mempengaruhi pendapat investor terhadap keuntungan di masa yang akan datang.

\section{Pengaruh Profitabilitas terhadap Return Saham}

Profitabilitas dengan menggunakan indikator ROE tidak berpengaruh terhadap return saham. Artinya, tinggi rendah profitabilitas tidak akan mempengaruhi investor dalam pengambilan keputusan investasinya. Apabila perusahaan mampu mengelola modalnya dengan baik maka akan mampu menghasilkan profit. Maka tidak semua perusahaan yang modalnya menurun akan berpengaruh pada return saham perusahaan tersebut. Hal ini didukung oleh penelitian Aisah dan Mandala (2016) yang menyatakan ROE tidak berpengaruh terhadap return saham.

\section{Pengaruh Economic Value Added terhadap Return Saham}

Dari hasil pengujian menunjukkan bahwa EVA tidak berpengaruh terhadap return saham. Hasil penelitian ini tidak sesuai dengan teori menurut Kartini dan Hermawan (2008, 
358) menyatakan EVA adalah suatu estimasi laba ekonomis yang sesungguhnya dari perusahaan dalam tahun berjalan. EVA menunjukkan sisa laba setelah semua biaya modal termasuk modal ekuitas dikurangkan. Prinsip EVA adalah memberikan sistem pengukuran yang baik untuk menilai suatu kinerja dan prestasi keuangan manajemen perusahaan karena EVA berhubungan langsung dengan nilai pasar suatu perusahaan. Sama seperti halnya profitabilitas, tinggi rendahnya EVA tidak akan mempengaruhi investor dalam mempengaruhi keputusannya.

Pengaruh Leverage, Profitabilitas, dan Economic Value Added terhadap Return Saham

Seluruh variabel independen, yaitu leverage, profitabilitas, dan EVA memiliki kemampuan dalam mempengaruhi return saham secara bersama-sama disebabkan karena investor dalam pengambilan keputusan investasi memandang penting penggunaan hutang dan EVA. Hal ini sesuai dengan penelitian Ruriana Ulfa (2011) dan Qodari dan Oetomo (2017) bahwa secara bersama-sama ketiga variabel independen tersebut berpengaruh signifikan terhadap return saham. Dalam hal ini dapat diartikan bahwa investor memperhatikan kemampuan perusahaan dalam menciptakan laba setelah dikurangi dengan biaya modal dan struktur hutang. Dengan leverage dan economic value added, maka return saham akan tinggi.

\section{PENUTUP}

Penelitian ini dilakukan untuk menganalisis pengaruh leverage, profitabilitas, dan economic value added terhadap return saham pada perusahaan makanan dan minuman yang terdaftar di BEI selama lima tahun dengan menggunakan data laporan keuangan tahunan yang telah diaudit yaitu untuk tahun 2012-2016. Hasil penelitian menunjukkan bahwa:

1. Secara parsial leverage yang menggunakan indikator debt to equity ratio berpengaruh signifikan terhadap return saham. Hasil ini memiliki arti bahwa DER berpengaruh terhadap return saham yang berarti jika kesempatan investasi yang diperoleh perusahaan dilihat melalui DER mengalami kenaikan, maka memiliki hubungan dengan rasio return saham bagi investor.

2. Secara parsial profitabilitas dan economic value added tidak berpengaruh secara signifikan terhadap return saham. Hasil ini menunjukkan bahwa tinggi rendahnya profitabilitas dan EVA, tidak akan mempengaruhi keputusan investor terkait investasinya.

3. Secara simultan menunjukkan bahwa leverage, profitabilitas, dan economic value added dengan leverage dihitung menggunakan indikator debt to equity ratio berpengaruh secara signifikan terhadap return saham yaitu capital gain. Hal ini menunjukkan bahwa kedua variabel independen secara bersamaan memberikan sumbangan pengaruh sebesar 16,1\% terhadap return saham.

\section{REFERENSI}

Afinindy, I. dan Budiyanto. (2017). Pengaruh $D E R, P E R, R O E$, terhadap Return Saham Perusahaan Telekomunikasi. Jurnal IImu \& Riset Manajemen Vol. 6 No. 6.

Aisah, Ayu dan Mandala, K. (2016). Pengaruh ROE, EPS, dan Operating Cash Flow terhadap Return Saham. E-Jurnal Manajemen Unud Vol. 5 No. 11, ISSN: 2302-8912.

Ansori. (2015). Pengaruh Economic Value Added dan Market Value Added terhadap Return Saham pada Perusahaan Manufaktur yang Terdaftar di Bursa Efek Indonesia, Skripsi, Yogyakarta, Universitas Negeri Yogyakarta.

Damayanti, O. (2015). Analisis Pengaruh Laba Akuntansi dan Komponen Arus Kas Terhadap Return saham Perusahaan (Studi Kasus pada Perusahaan LQ 45 yang Terdaftar di BEI Tahun 2010-2013), 
Skripsi, Jakarta, Universitas Mercubuana.

Fahmi, I. (2012). Pengantar Manajemen Keuangan, Bandung: Penerbit Alfabeta CV. . (2013). Pengantar Pasar Modal Panduan bagi Para Akademisi dan Praktisi Bisnis Dalam Memahami Pasar Modal Indonesia, Bandung: Penerbit Alfabeta CV. (2014). Manajemen Keuangan Perusahaan dan Pasar Modal, Edisi Pertama, Jakarta, Penerbit Mitra Wacana Media.

Ghozali, I. (2013). Aplikasi Analisis Multivariate dengan Program SPSS, Edisi Ketujuh, Semarang, Badan Penerbit Universitas Diponegoro.

Gejali, I. dan Satrio, B. (2013). Pengaruh Current Ratio, Return on Equity, dan Earning Per Share terhadap Return Saham. Jurnal Ilmu \& Riset Manajemen Vol. 2 No. 6.

Hartono, J. (2013). Teori Portofolio dan Analisis Investasi, Edisi Kesepuluh, Yogyakarta, Penerbit BPFE Yogyakarta.

Hery, H. (2013). Analisis Pengaruh Earning Per Share (EPS), Net Profit Margin (NPM), dan Return On Asset terhadap Return Saham Perusahaan Sektor Asuransi di Bursa Efek Indonesia Periode 2007-2010, Skripsi, Jakarta, Universitas Islam Negeri Syarif Hidayatullah.

. (2016). Analisis Laporan Keuangan. Jakarta. Penerbit Grasindo.

Kartini dan Hermawan, Gatot. (2008). Economic Value Added dan Market Value Added terhadap Return Saham, Jurnal Keuangan dan Perbankan, Volume 12, hal 355-368.

Marshal, Y. (2009). Pengaruh Economic Value Added, Market Value Added dan Arus Kas Operasi Terhadap Return Saham, Skripsi, Medan, Universitas Sumatera Utara.

Pratiwi, Eka Novia A. (2017). Pengaruh Laba Bersih, Arus Kas Operasi, dan Ukuran
Perusahaan Terhadap Return Saham (Studi pada Perusahaan LQ 45 yang Terdaftar di BEI Tahun 2011-2015), Skripsi, Bogor, Universitas Pakuan.

Purwanto, Erwan A., dan Sulistyastutih, Dyah R. (2017). Metode Penelitian Kuantitatif, Edisi Kedua, Jogjakarta: Penerbit Gava Media.

Qodari, Nur L. dan Oetomo, Hening W. (2017). Pengaruh Growth, DFL, dan ROE terhadap Return Saham pada Perusahaan Pertambangan Batubara di $B E I$. Jurnal Ilmu \& Riset Manajemen Vol. 6 No. 1.

Sari, Latipah R. dan Sugiyono. (2016). Pengaruh NPM, ROE, EPS terhadap Return Saham pada Perusahaan Farmasi di BEl. Jurnal Ilmu \& Riset Manajemen Vol. 5 No. 12.

Santoso, S. (2012). Analisis SPSS pada Statistik Parametrik, Jakarta, PT Alex Media Komputindo.

Ulfa, R. (2011). Pengaruh Ukuran Perusahaan, Leverage, Economic Value Added, Return on Investment, dan Earning Per Share terhadap Return yang Diterima oleh Pemegang Saham, Skripsi, Jakarta, Universitas Islam Negeri Syarif Hidayatullah.

Utami, P. (2015). Pengaruh Likuiditas, Profitabilitas Dan Economic Value Added terhadap Harga Saham Perusahaan Manufaktur (Studi Empiris di Bursa Efek Indonesia Tahun 2009-2013), Skripsi, Surakarta, Universitas Muhammadiyah Surakarta.

Utari, D. et al, (2014). Manajemen Keuangan Kajian Praktik dan Teori dalam Mengelola Keuangan Organisasi Perusahaan, Edisi Revisi. Jakarta: Penerbit Mitra Wacana Media.

Utomo, Seno J. (2011). Pengaruh Arus Kas Operasi dan Laba Akuntansi Terhadap Return Saham pada Perusahaan Manufaktur di Bursa Efek Indonesia, Skripsi. Semarang: Universitas Negeri Semarang. 
Yatulhusna, N. (2015). Pengaruh Profitabilitas, Leverage, Umur, dan Ukuran Perusahaan Terhadap Manajemen Laba Stude Empiris pada Perusahaan Manufaktur yang Terdaftar di Bursa Efek Indonesia Periode 2010-2013, Skripsi, Jakarta: Universitas Islam Negeri Syarif Hidayatullah.

Widodo, Wahyu A. (2016). Pengaruh Economic Value Added (EVA) Momentum, Debt Equity Ratio (DER), Net Profit Margin (NPM), Return on Asset (ROA), Return On Equity (ROE) terhadap Kinerja Pasar, Skripsi. Surakarta: Universitas Muhammdiyah Surakarta. 